\title{
Persistencer of Rubella Antibody with and without Embryopathy A Follow-up Study of Children Exposed to Maternal Rubella
}

\author{
N. R. BUTLER,* M.D., F.R.C.P. ; J. A. DUDGEON,* M.C., M.D., F.C.PATH. ; KATHLEEN HAYES,* M.B., B.S. ; \\ CATHERINE S. PECKHAM, $\dagger$ M.B.; KENNETH WYBAR,* M.D., CH.M., F.R.C.S.
}

Brit. med. F., 1965, 2, 1027-1029

The serious consequences to the foetus of rubella in early pregnancy have been well and fully documented (Lundström, 1952, 1962 ; Manson et al., 1960). Apart from major abnormalities associated with the rubella syndrome (cataract, deafness, heart lesions, microcephaly, and mental retardation), defects may occur which are not apparent at birth or in the first year or so of life. This applies particularly to defects of hearing. In a large inquiry in Britain in 1950-2 (Manson et al., 1960) the incidence of deafness in children 2 years of age whose mothers had contracted rubella in the first 12 weeks of pregnancy was $2.7 \%$ (5 out of 183 ), with a possible addition of $3.3 \%$ for children with suspected deafness.

In addition to major and minor defects commonly associated with maternal rubella nearly all infants with the rubella syndrome develop an active immune response and not immunological tolerance as might be expected (Plotkin et al., 1963). The persistence of antibody in the absence of a history of post-natal rubella enables a retrospective diagnosis of congenital rubella to be made (Weller et al., 1964 ; Dudgeon et al., 1964). Persistence of antibody has also been demonstrated in children exposed to maternal rubella but in whom no deformity was noticed in the first year of life (Dudgeon et al., 1964).

An opportunity to study the factors that determine whether foetal damage or subclinical infection ensues after maternal rubella was afforded by a current longitudinal study in the Public Health Laboratory Service of some 27,000 women who were given gamma-globulin between 1954 and 1962 because they had been exposed to rubella in early pregnancy. A small proportion of the women developed rubella in spite of gamma-globulin (McDonald, 1963), and a few others were given gamma-globulin after the onset of illness in the hope of protecting the foetus. The present report describes a clinical and serological study of a selected sample of the children from these pregnancies made when they were 1-3 years of age. The question of the overall effectiveness of gamma-globulin in preventing congenital defects due to rubella will not be considered in this paper as it is the subject of the more extensive Public Health Laboratory Service inquiry.

\section{Materials and Methods}

\section{Group Studied}

The patients under investigation consisted of 34 male and 36 female children aged 1-3 years living in the London area or the Home Counties, and in all of whom the family doctor had reported that there was no obvious rubella defect at the time of birth or within the first few months of life. A preliminary postal inquiry prior to re-examination had revealed a number of cases of deafness. The stage in pregnancy at which maternal infection occurred ranged from four to twenty-five weeks, although the majority occurred between nine and sixteen weeks. All the mothers had received gamma-globulin before or after the onset of rubella. In 49 cases it was given at some time

The Hospital for Sick Children, Great Ormond Street, London, W.C.1. t The Epidemiological Research Laboratory, Colindale. between contact and the onset of the rash ; in 37 cases 5-28 days before the rash ; in four cases within four days of the rash, and in eight cases more than 28 days previously. The remaining 21 mothers received gamma-globulin after the onset of the rash.

Medical examination and ophthalmic and auditory testing of the children were all carried out at one visit to a weekly immunology clinic arranged for this purpose between November 1964 and April 1965 at the Hospital for Sick Children, Great Ormond Street. A past and family history was taken in order to exclude as far as possible any other causes for defects. On physical examination special attention was paid to the cardiovascular system, and where necessary an electrocardiogram and a chest $x$-ray film were taken. Assessment of hearing was carried out with the Stycar test devised by Sheridan (1958). This test aims at determining the child's ability to hear speech and to respond to it appropriately in the environment of an ordinary room. In the test, pictures and toys are used with common names containing vowels and consonants representing the speech range as adequately as possible. The responses of the child to sounds of different frequency were also noted. Ability to vocalize and to manipulate toys was also observed and a record made of the mother's history regarding the child's speech and hearing.

The ophthalmic examination was directed particularly to the lenses and fundi after the use of a mydriatic (cyclopentolate $1 \%$ drops). A short routine examination was also carried out (the pupillary reactions to light, the ocular movements, and the cover-uncover test) after taking a history from the mother of any suggestion of visual impairment. There is a known association between cataractous changes and retinal pigmentary changes (embryopathic pigmentary retinopathy) in a child following maternal rubella in early pergnancy.

\section{Virological Studies}

These consisted of serological and virus isolation tests. Blood for assay of rubella neutralizing antibody was collected from each mother and child in the study group. Sera from two control groups of children aged 1-3 years were also studied. These came from a random series of 36 children admitted to this hospital and from 27 children with classical rubellasyndrome defects. Sera were tested in RK 13 cells (a transformed line of rabbit kidney cells) against 100 tissue-culture doses of rubella virus by the method described by Dudgeon et al. (1964). The antibody titre was expressed as the reciprocal of the serum dilution in which there was partial inhibition of the cytopathic effect of rubella virus. Sera with antibody titres of 4 or greater were regarded as seropositive, and those with titres of less than 4 as seronegative. Known positive and negative sera were included with each series of titrations.

Nose and throat swabs were taken from 27 of the younger patients and placed into virus transport medium containing antibiotics. These specimens were inoculated within 24 hours of collection into primary green African monkey kidney cells and 
RK 13 cells according to the methods previously described for isolation of rubella virus (Parkman et al., 1962 ; McCarthy et al., 1963). Monkey-kidney cultures were challenged on the seventh day with E.C.H.O. 11 virus. RK 13 cultures were examined for cytopathic changes. Cultures were regarded as negative if there was no evidence of the presence of virus after two passages.

\section{Results}

Table I shows the number of children in the study group with and without rubella defects, their serological status, and the week in pregnancy of exposure to maternal rubella.

\begin{tabular}{|c|c|c|c|c|c|c|c|c|c|}
\hline & \multirow{2}{*}{$\begin{array}{l}\text { Immune } \\
\text { Status }\end{array}$} & \multicolumn{8}{|c|}{$\begin{array}{c}\text { Week of Pregnancy when Exposed to } \\
\text { Maternal Rubella }\end{array}$} \\
\hline & & $0-4$ & $5-8$ & 9-12 & $\begin{array}{c}13- \\
16\end{array}$ & $\begin{array}{c}17- \\
20\end{array}$ & $\begin{array}{c}21- \\
24\end{array}$ & $\begin{array}{c}25- \\
28\end{array}$ & Total \\
\hline $\begin{array}{l}\text { Without rubella }\{ \\
\text { defects }\end{array}$ & $\begin{array}{l}\text { Seropositive } \\
\text { Seronegative } \\
\end{array}$ & 1 & 2 & $\begin{array}{l}6 \\
8\end{array}$ & $\begin{array}{r}7 \\
12\end{array}$ & $\begin{array}{l}5 \\
5\end{array}$ & $\begin{array}{l}0 \\
1\end{array}$ & $\begin{array}{l}0 \\
1\end{array}$ & $\begin{array}{l}21 \\
29\end{array}$ \\
\hline $\begin{array}{c}\text { Total without } \\
\text { defects }\end{array}$ & & 1 & 4 & 14 & 19 & 10 & 1 & 1 & 50 \\
\hline 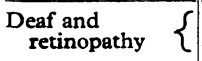 & $\begin{array}{l}\text { Seropositive } \\
\text { Seronegative }\end{array}$ & 二 & 1 & 7 & 二 & - & E & E & $\begin{array}{l}8 \\
0\end{array}$ \\
\hline Deaf $\quad \ldots\{$ & $\begin{array}{l}\text { Seropositive } \\
\text { Seronegative }\end{array}$ & - & 1 & 1 & $\underline{2}$ & - & - & - & $\begin{array}{l}4 \\
0\end{array}$ \\
\hline Retinopathy \{ & $\begin{array}{l}\text { Seropositive } \\
\text { Seronegative }\end{array}$ & 二 & 2 & 2 & 1 & $\begin{array}{l}1 \\
1 \\
\end{array}$ & $\overline{1}$ & 二 & $\begin{array}{l}6 \\
2 \\
\end{array}$ \\
\hline $\begin{array}{cc}\text { Total with rubella } \\
\text { defects } \\
\end{array}$ & & 0 & 4 & 10 & 3 & 2 & 1 & 0 & 20 \\
\hline Total cases & & 1 & 8 & 24 & 22 & 12 & 2 & 1 & 70 \\
\hline
\end{tabular}

Fifty of the 70 children examined showed no clinical evidence of rubella syndrome defects, although 10 of these had other conditions-namely, speech retardation without hearing loss (four cases), past pyloric stenosis (two), past history of mild talipes equinovarus (two), non-structural scoliosis (one), and squint (one). Nine children had a soft Grade I systolic murmur which was thought to be functional. Of these, four were deaf, one had retinopathy, and four were without rubella defects. Twenty children were found to have defects usually associated with congenital rubella-deafness alone (four), pigmentary retinopathy alone (eight), or deafness and retinopathy together (eight). The twelve cases of deafness, all of which occurred after maternal rubella in the first 16 weeks of pregnancy, were bilateral and associated with marked speech retardation; in two this had not previously been suspected.

Of the 16 cases of pigmentary retinopathy 11 were bilateral. Most of these followed rubella in the first 16 weeks, but three occurred after rubella between the 17 th and the 24 th week. Embryopathic pigmentary retinopathy is a fairly constant finding in congenital rubella, although a similar anomaly of the pigment epithelium of the retina may follow certain other forms of maternal infection, such as syphilis and "influenza," when they occur in the early months of pregnancy. The condition usually affects both eyes and is the result of an interference with normal development of the pigment epithelium of the retina, so that in some areas the cells are more or less devoid of pigmentation, whereas in other areas the cells contain an excess of unusually large pigment granules. This anomaly also accounts for the characteristic appearance in the fundus of small bluish pigmented spots-the so-called pepper-and-salt changes. In this series these pigmentary changes did not seem to have caused any obvious visual disturbance.

No case of cataract, microcephaly, or congenital heart disease was detected.

Table II shows the proportion of children with and without antibody in the study and control groups.

Of the 70 sera from these children aged $1-3$ years $39(55.7 \%)$ were seropositive, with antibody titres ranging from 8 to 256 ;
31 were seronegative. Of the 50 children without rubella defects 21 were seropositive $(42 \%)$ and $29(58 \%)$ were seronegative. The incidence of antibody in the control series of 36 " normal" children of the same age group was $5.6 \%$. A close correlation was found between the incidence of antibody and the presence of defects. Of the 20 children with defects 18 (90\%) were seropositive, an incidence which was very similar to that of $85 \%$ seropositive found in children of the same age with classical

Table II.-Serological Status of Children Aged 1 to 3 Years in Study

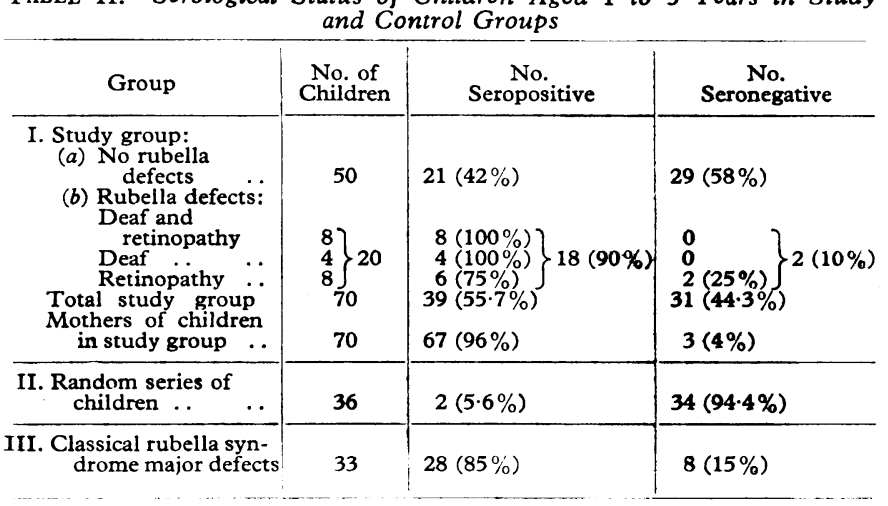

rubella syndrome defects. All the children with deafness, with or without retinopathy, were seropositive. Six of the eight children with retinopathy alone were seropositive, but two were seronegative. In the case of the mothers of these children; 67 had antibody, but in three cases both mother and child were seronegative. Two of these three children were without defects and the other had retinopathy.

Nine children with rubella defects were noted among 37 children whose mothers had been given prophylactic gammaglobulin 5 to 28 days before the onset of the rash, and a further three children with defects were observed in four whose mothers had been given gamma-globulin within four days of the onset of the rash. Eight rubella defects were noted among the 21 children whose mothers received gamma-globulin after onset of the rash. There were no defects in eight children whose mothers had received gamma-globulin more than 28 days before onset of the rash.

Attempts to isolate virus from the nose and throat of 27 of the younger patients were unsuccessful.

\section{Discussion}

Perceptive deafness is a well-recognized sequel to maternal rubella, and the importance of re-examination to detect undiagnosed cases has been well illustrated in the series of Manson et al. (1960). Serial medical examinations of many in that series showed a much higher incidence than the $6 \%$ originally reported at 2 years of age (Manson et al., 1960). A re-examination of 156 of these children born after maternal rubella in the first 16 weeks of pregnancy revealed 20 cases of perceptive deafness $(13 \%)$ at the age of 3-7 years. Deafness had not previously been detected in 13 of these 20 cases, but no additional major defects were found. Jackson and Fisch (1958) found an even higher incidence of hearing loss in a group of these children aged 3-5 years living in the London area. Fourteen out of 46 children $(30.4 \%$ ) with defects were detected by audiometry. In nine of these children deafness had not previously been detected, and six had severe bilateral deafness. A reassessment by Sheridan (1964) on 227 children from the Manson series when aged 8-11 years revealed 43 (19\%) cases of significant deafness, 17 of which (10 bilateral and 5 severe) had not been detected on previous examinations. Barr and Lundström (1961) carried out a prospective audiometric survey of 46 children whose mothers had a history of rubella in the 1950-51 epidemic in Sweden. They found that the hearing 
loss in 44 children (two could not be traced) examined at the age of 6-8 years was $22 \%$; severe deafness was present in $8 \%$. Thus the overall incidence of congenital perceptive deafness in several hundred children exposed to maternal rubella in the first 16 weeks of pregnancy appears to be of the order of $16-22 \%$. In the series now reported 12 children out of $55(22 \%)$ were found to have hearing loss, either deafness alone or with retinopathy, following maternal rubella in the first 16 weeks of pregnancy.

The finding of more than one stigma is by no means uncommon in cases of rubella embryopathy. For example, congenital heart disease, cataracts, or deafness in the same patient are not uncommon. In many of these a pigmentary retinopathy also occurs, although sometimes the cataract is so dense that it prevents a clear view of the fundus. In this series 16 of the 70 children were found to have a pigmentary retinopathy, and half of these also had hearing loss, so that the presence of retinopathy is a useful additional " marker" of congenital rubella. Although this congenital anomaly is not specific for rubella, it seems to occur with greater frequency after maternal rubella than any other infection. Two of the cases with retinopathy were seronegative. The explanation for the absence of antibody in these patients is not clear. In one instance, however, the mother was also seronegative, so that some agent other than rubella could have been responsible for the maternal illness.

The serological findings on these children show a close correlation between the presence of antibody and of defects. This is consistent with earlier findings that antibody persistence is a regular feature of the rubella syndrome. Apart from the two cases of retinopathy, all the patients with defects were seropositive. In previous series a few cases of seronegative children with what appeared to be classical rubella syndrome defects have been reported (Weller et al., 1964 ; Dudgeon et al., 1964), so presumably a few patients without antibody might be expected among children with minor defects. Whether the absence of antibody is due to immunological tolerance, to decay in rubella antibody, or to infection with another agent is not known.

The serological findings on the 50 children without defects showed a far higher proportion of seropositives than in their normal cohorts. In the absence of any history of post-natal infection with rubella it is postulated that the antibody in these children resulted from a subclinical infection during early foetal life. Thus it appears that foetal infection during the first and second trimesters of pregnancy can lead to seroconversion in the foetus without resulting embryopathy. The fact that the serological results in this group were the same in children whose mothers had received gamma-globulin before and those receiving it after the onset of rubella suggests that this finding was not related to the use of gamma-globulin.

It is clear from these results that gamma-globulin does not give the foetus complete protection from rubella, a fact that is already known; but the number of children so far examined in this investigation is too small for conclusions to be drawn concerning the overall effectiveness of gamma-globulin in preventing rubella defects in pregnancy. The answer to this, and to the important question of whether the prevention of rubella with gamma-globulin is accompanied by protection of the foetus, must await the results of the Public Health Laboratory Service Inquiry.

\section{Summary}

A clinical and laboratory investigation is reported on 70 children aged 1-3 years exposed to maternal rubella in pregnancy. The mothers of these children had been given gammaglobulin after exposure to rubella.

Fifty children were found to have no clinical evidence of rubella syndrome defects ; $42 \%$ of these showed persistence of rubella antibody. Twenty children were found to have rubella defects-deafness (four), retinopathy (eight), or deafness and retinopathy (eight); $90 \%$ of these were seropositive. Six per cent. of a random control group, and $85 \%$ of a group with classical rubella syndrome defects were seropositive. These findings suggest that a subclinical rubella infection leading to seroconversion can occur in the first 20 weeks of pregnancy without subsequent clinical defects in the child.

We wish to express our grateful thanks to Dr. Mary Sheridan for her constant help and advice throughout this investigation, to Dr. T. M. Pollock, Director of the Epidemiological Research Laboratory at Colindale, and to Dr. J. C. McDonald, McGill University, Montreal, for helpful advice and criticism. Also to the medical and nursing staff at the Hospital for Sick Children, to Mr. B. R. James, A.I.M.L.T., and other technical staff at the hospital, for their assistance with the virological studies, and to the clerical staff of the Epidemiological Research Laboratory at Colindale.

Dr. Catherine S. Peckham and Dr. Kathleen Hayes are both in receipt of grants from the Medical Research Council.

\section{REFERENCES}

Barr, B., and Lundström, R. (1961). Acta oto-laryng. (Stockh.), 53, 413. Dudgeon, J. A., Butler, N. R., and Plotkin, S. A. (1964). Brit. med. F., 2, 155 .

Jackson, A. D. M., and Fisch, L. (1958). Lancet, 2, 1241.

Lundström, R. (1952). Acta paediat. (Uppsala), 41, 583.

- (1962). Ibid., 51, Suppl. No. 133.

McCarthy, K., Taylor-Robinson, C. H., and Pillinger, S. E. (1963) Lancet, 2, 593.

McDonald, J. C. (1963). Brit. med. F., 2, 416.

Manson, M. M., Logan, W. P. D., and Loy, R. M. (1960). "Rubella and other Virus Infections during Pregnancy." Reports on Public Health and Medical Subjects, No. 101. Ministry of Health, H.M.S.O., London.

Parkman, P. D. Buescher, E. L., and Artenstein, M. S. (1962). Proc. Soc. exp. Biol. (N.Y.), 111, 225.

Plotkin, S. A., Dudgeon, J. A., and Ramsay, A. M. (1963). Brit. med. F., 2,1296 .

Sheridan, M. D. (1958). Manual for the Stycar Hearing Test, distributed by the National Foundation for Educational Research in England and Wales, London.

- (1964). Brit. med. F., 2, 536.

Weller, T. H., Alford, C. A., and Neva, F. A. (1964). New Engl. 7. Med., 270, 1039. 